\title{
進行性膀脱腫瘍に対する術前照射の近接効果
}

$\begin{array}{cccccc} & \text { 井 } & \text { 坂 } & \text { 茂 } & \text { 夫 } \\ & \text { 五 } & \text { 十 嵐 } & \text { 辰 } & \text { 男 } \\ \text { 千葉大学医学部泌尿器科 } & \text { 伊 } & \text { 藤 } & \text { 晴 } & \text { 夫 } \\ & \text { 村 } & \text { 上 } & \text { 光 } & \text { 右 } \\ & \text { 秋 } & \text { 元 } & & \text { 普 } \\ & \text { 島 } & \text { 崎 } & & \text { 淳 } \\ \text { 千葉大学医学部第 1 病理学教室 } & \text { 松 } & \text { 歌 } & & \text { 理 } \\ \text { 放射線医学総合研究所 } & \text { 森 } & \text { 田 } & \text { 新 } & \text { 六 } \\ & \text { 恒 } & \text { 元 } & & \text { 博 } \\ \text { 済生会宇都宫病院泌尿器科 } & \text { 中 山 } & \text { 朝 } & \text { 行 }\end{array}$

\section{EARLY EFFECTS OF PREOPERATIVE RADIATION THERAPY FOR INVASIVE BLADDER CANCER}

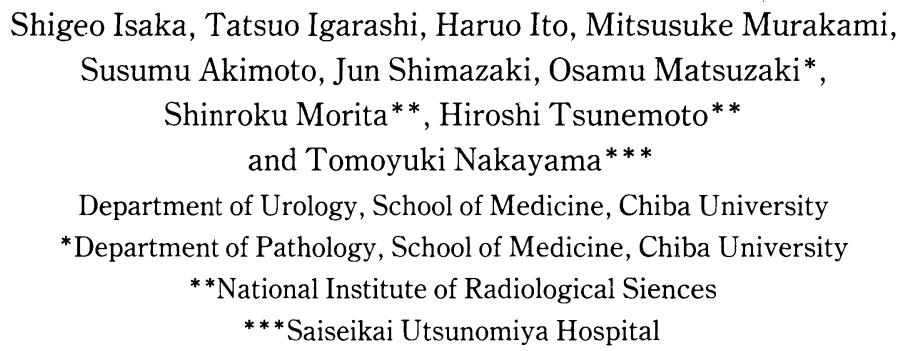

22 patients with high grade invasive bladder cancer were treated with preoperative radiation therapy ( 910 rad by fast neutron or 3000 rad by X ray during 2 weeks) followed by radical cystectomy and urinary diversion. $62.5 \%$ of patients showed reduction in tumor size more than $50 \%$ evaluated by cystogram. Stage down was observed in $38 \%$ of patients compared between clinical and pathological stage. Histopathological effect of GII or GIII, according to the criteria described by Ohboshi, was noticed in $79 \%$ of the patients. Better effect seemed to be obtained in fast neutron treated group than in X ray group.

19 patients received curative operation, and 18 patients are alive without recurrence for 10 months (mean observed term). One has died from lung metastasis 4.5 months after operation. $50 \%$ of the patients complained of side effects of irradiation although they were tolerable, and $32 \%$ of the patients had major complications of operation.

要旨：22例の進行性膀胱腫瑒患者に対して, 速中性子線910 $\mathrm{rad}$ 又はX線 $3,000 \mathrm{rad}$ の術前照射を行い, そ の後膀羘全摘術と尿路変更を行つた。 $62.5 \%$ の患者において, 膀胼造影の計測で $50 \%$ 以上の腫瘍縮小効 果を認めた. clinical stage と pathological stage を比較したところ $38 \%$ において stage down effectを 認めた. 大星の分類に基いて病理学的照射効果を検討したところ，79\%に GII もしくは GIII の効果を認 めた。速中性子線照射群に照射有効例を多く認めた。

治癒切除を19例に施行し，らち18例は平均観察期間10力月再発なく生存中である.術後4.5力月に肺転 移のため死亡した 1 例を認めた。照射による軽い副作用を $50 \%$ に認め，術後の合併症を $32 \%$ に認めた。 


\section{緒言}

浸潤型膀胱癌に対する治療方針としては，膀脱全摘 除術が選ばれることが多いが，膀胱全摘除術の予後は 未だ不良である。その主な原因は局所再発がしばしば 和こり，その結果として癌死が多いためであろう。我令 は膀胱全摘除術後の局所再発を予防し，ひいては予後 改善する目的で，昭和56年 1 月より術前照射を開始 した。本報は第 1 報として近接効果すなわち術前照射 の腫瘍組織に対する影響と、リニアックによるX線と 速中性子線との比較につき述べる。

\section{対象}

昭和 56 年 1 月より昭和 57 年 7 月までの期間に千葉大 学泌尿器科招よび済生会宇都宮病院泌尿器科を受診 し, 膀脱全摘除術の適応であると判断された原発性膀 胱癌患者22名対象とした。男性18名, 女性 4 名で, 年龄は 49 歳から74歳まで平均 64.6 歳であつた。

診断怯, 膀胱鏡検查, 尿細胞診, IVP， 5 方向膀胱造 影, 麻酔下双手䛦, 生検, 経尿道的超音波断層法, CT, 骨盤血管造影, リンパ管造影などにより, 膀胱全摘除 術の適応は, Grade 2 は $\mathrm{T}_{3}$ 以上を, Grade 3 は $\mathrm{T}_{1}$ 以上 とした。腫瘍の組織型は移行上皮癌19例, 扁平上皮癌 3 例でめり, 異型度は, G2：5 例，G2と G3の混在： 2 例, G3：15例であつた ${ }^{11}$.

術前照射に使用した機種は, サイクロトロン（放射 線医学総合研究所）11例，リニアック11例であつた。

施行した術式は, 骨盤内リンパ節郭清を伴う根治的 膀胱全摘除術が17例，郭清を伴わない膀胼全摘除術が 4 例, 摘出不能が 1 例でめり, 治癒切除 19 例, 非治癒 切除 3 例であつた。尿路変更術は, 回腸導管造設術 17 例，尿管皮膚瘻術 5 例であつた。この選択基準として， 高齢者および進行癌などは後者によつた。術後14例に ついては化学療法（MFC）を招こなつた。

（照射方法）

照射野は膀胱全体とし, 膀胱造影像と CT を参考と した。内尿道口近くの腫瘍は，尿道側に照射野を広げ た。回腸導管手術の不利益とならないように，消化管 の被曝は極力避けるように努めた。このためリンパ節 は膀㬺近くのリンパ節の一部が照射野に含まれたのみ である。

装置と線量：サイクロトロン使用の場合は速中性子 線 1 回130rad を週 3 回，計 7 回910 rad 前後 2 門照 射で行つた。リニアック使用の場合は，X線 1 回300 $\mathrm{rad}$ を週 5 回，計10回3,000 $\mathrm{rad}$ 前後 2 門で，前 2 回 に対し後 1 回の割で照射を行つた。両群共TDFは60
であり比較対照が可能である．照射終了後手術までの 期間は 5 〜 日とした。

(近接効果の判定方法)

腫瘍縮小効果を，照射前後における膀脱造影の陰影 欠損の長径と短径の積を比較することにより判定し た。

Clinical stage ( $\mathrm{T}$ ) 各種臨床検查結果により総合 判定し, 摘出標本で判定された Pathological stage (P) と比較した。

照射の病理組織学的効果判定大星の分類 ${ }^{2}$ に準拠 して行った。

\section{結 果}

(1) 腫煌縮小効果：陰影欠損を呈しなからたもの㐫 るいは照射前後が比較できなかつたもの14例を除いた 8 例につき，照射前後に和ける比較を和こなつた（表 1). $50 \%$ 以上縮小した症例はサイクロトロン照射例に 4 例，リニアック照射例飞 1 例，計 5 例であり，判定

表 1 腫瘍縮少効果

(膀胼造影による計測)

\begin{tabular}{|c|c|c|}
\hline & サイクロトロン & リニアック \\
\hline $50 \%$ 以上縮少 & 4 & 1 \\
\hline 25 50\%縮少 & 1 & 1 \\
\hline 不変 & 0 & 1 \\
\hline 判, 定 不能 & 6 & 8 \\
\hline
\end{tabular}

図 1（a）照射前

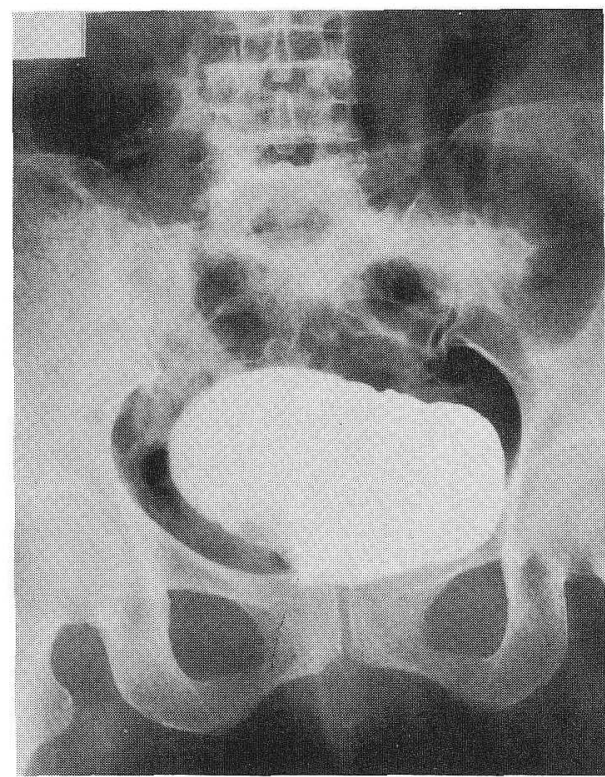




\section{図 1 （b）照射後}

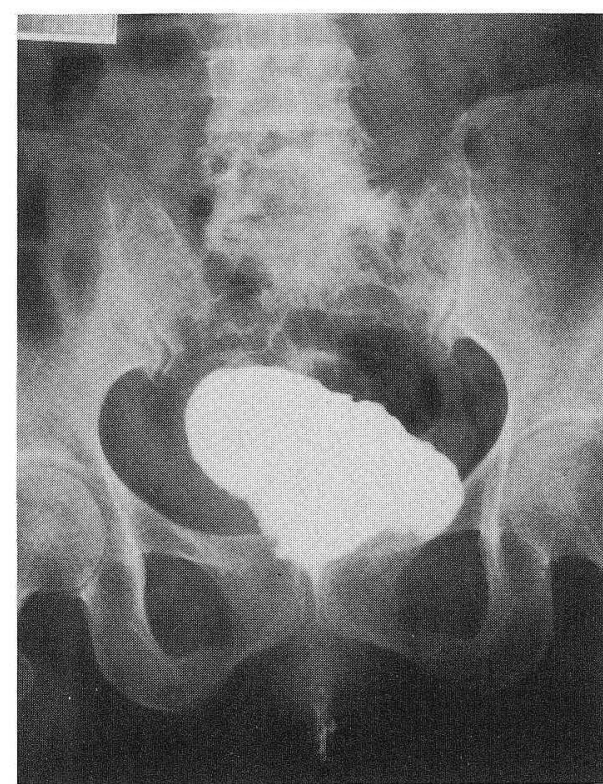

可能であつた 8 例のらち $62.5 \%$ 占めた。

腫瘍縮小効果を示した 1 症例のレンドゲン写真を図 示寸る (図 1). 照射前に比し照射後の陰影欠損部分は $45 \%$ 縮小している。

(2) Clinical stage ( $\mathrm{T}$ ) と Pathological stage (P): $\mathrm{P}$ がTに比し低い場合を stage down effect として評 価した。サイクロトロン照射10例中 5 例(50\%)，リニ アック照射11例中 3 例 (27\%) が down staging を示 し, 全体の down staging rate は38\%であつた(表 2$)$.

(3) 病理組織学的効果: GI : 4 例, GIIa：9 例, GIIb： 4 例, GIII：2 例であり,サイクロトロンとリニ アックの間では差を認めなかつた(表 3 ). 組織学的異 型度と病理組織学的効果の対照を表 4 に示した。異型
度 G2群に比し，G3群で良好な照射効果を示した症例 が多く, 異型度の強い腫瘍に效果が強くあらわれるこ とがうかが壳る。

代表例飞䑙ける照射前後の病理組織所見を図 2 亿示 す。照射前の経尿道的パンチ生検の標本では, 腫瘍細 胞は索状に間質内へ浸潤を示し, 強い核異型性が認め られ，非乳頭状浸潤性移行上皮癌 Grade 3の所見であ る. 照射後の全摘標本では, 粘膜下に強い線維化と好 酸球を含さ細胞浸潤を認め，その間に核の濃縮などの 変性が強く, 核内ないし胞体内に空胞化を伴う腫瘍細 胞の残存が認められる。照射効果は GIIbであつた。

(予後)

治癒切除をな乙得た19例の予後は, 術後 4 カ月で肺 転移の為死亡した 1 例を除き，18例は癌の再発転移な く生存中であり, 経過観察期間は最長 19 力, 平均 10 カ月である.19例全例局所再発認められない(表 5 )。 な打今回の観察では術後の化学療法の評価をのぞい た. 非治癒切除を行つた 3 例のうちわけは, 肝転移 2 例，リンパ節転移 1 例であつた。

全体で手術死亡（術後 1 力月以内の死亡） 1 例 (4.5\%) で脳出血によるものであつた。

（副作用之合併症）

照射中に発生した副作用を表 6 に示した。11例 (50\%)に何らかの副作用を認めた。呕気，呕吐，食思 不振, 下痢, 腹痛等の消化器症状を 7 例に認めた。頻 尿が 2 例, 照射部位の皮膚の発赤硬化を 1 例に認めた。 以上の副作用は治療計画の变更は必要としなかつた。

照射による組織反応のため尿管閉塞をきた乙，急性 腎不全を発症した症例が 1 例あつた。本症例は緊急の 尿路变更術に上り救命され，その後膀胱全摘除術を受 け生存中である。

術後合併症を表 7 に示した。 7 例（32\%）に術後合

表 2 Clinical stage そ Pathological stage

サイクロトロン照射例

\begin{tabular}{ll|lllll}
\hline \multirow{2}{*}{$\begin{array}{c}\text { Clinical } \\
\text { stage }\end{array}$} & \multicolumn{6}{c}{ Pathological stage } \\
\cline { 2 - 6 } & $\mathrm{P}_{0}$ & $\mathrm{P}_{1}$ & $\mathrm{P}_{2}$ & $\mathrm{P}_{3 \mathrm{a}}$ & $\mathrm{P}_{3 \mathrm{~b}}$ & $\mathrm{P}_{4}$ \\
\hline $\mathrm{T}_{1}$ & & & & & & \\
\hline $\mathrm{T}_{2}$ & & & & & & \\
\hline $\mathrm{T}_{3 \mathrm{a}}$ & & & & & 1 \\
\hline $\mathrm{T}_{3 \mathrm{~b}}$ & & 1 & 3 & 4 \\
\hline $\mathrm{T}_{4}$ & & & & & \\
\hline
\end{tabular}

down stagig rate $=50 \%$
リニアック照射例

\begin{tabular}{|c|c|c|c|c|c|c|}
\hline \multirow{2}{*}{$\begin{array}{l}\text { Clinical } \\
\text { stage }\end{array}$} & \multicolumn{6}{|c|}{ Pathological stage } \\
\hline & $\mathrm{P}_{0}$ & $\mathrm{P}_{1}$ & $\mathrm{P}_{2}$ & $\mathrm{P}_{3 \mathrm{a}}$ & $\mathrm{P}_{3 \mathrm{~b}}$ & $\mathrm{P}_{4}$ \\
\hline $\mathrm{T}_{1}$ & 1 & 1 & & & & \\
\hline $\mathrm{T}_{2}$ & & & 2 & & & \\
\hline $\mathrm{T}_{3 \mathrm{a}}$ & & & 1 & & & \\
\hline $\mathrm{T}_{3 \mathrm{~b}}$ & & & & 1 & 4 & \\
\hline $\mathrm{T}_{4}$ & & & & & & 1 \\
\hline
\end{tabular}

over all down staging rate $=38 \%$ 
表 3 病理組織学的効果

\begin{tabular}{ccccc}
\hline & \multicolumn{4}{c}{ Pathological effect } \\
\cline { 2 - 5 } & G I & G II a & G II b & G III \\
\hline サイクロトロン & 3 & 4 & 3 & \\
\hline リ & 1 & 5 & 1 & 2 \\
\hline 計 & 4 & 9 & 4 & 2 \\
\hline
\end{tabular}

表 4 病理組織学的効果と異型度

\begin{tabular}{ccccc}
\hline \multicolumn{5}{c}{ Pathological effect } \\
\hline 異型度 & G I & G II a & G II b & G III \\
\hline G 2 & 2 & 3 & & \\
\hline G $2 \geqq$ G 3 & 1 & & 1 & \\
\hline G 3 & 1 & 6 & 3 & 2 \\
\hline
\end{tabular}

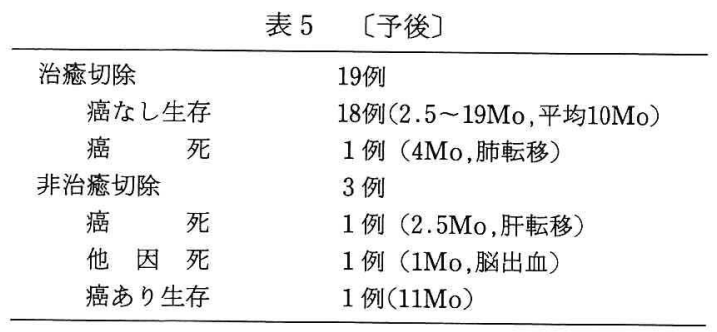

表 6 〔照射中の副作用〕

\begin{tabular}{|c|c|c|}
\hline & $\begin{array}{c}\text { サイクロトロン } \\
6 \text { 例 }\end{array}$ & 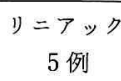 \\
\hline 嘔気・嘔吐・食思不振 & 3 & 1 \\
\hline 下＼cjkstart峲 & 0 & 1 \\
\hline 腹痛 & 1 & 1 \\
\hline 頻尿 & 1 & 1 \\
\hline 皮膚反応 & 1 & 0 \\
\hline 㽷管閉塞・腎不全 & 1 & 0 \\
\hline 計 & \multicolumn{2}{|c|}{11 例(50\%) } \\
\hline
\end{tabular}

併症を認めた。照射との関係が疑われるものは，創感 染 2 例, 創哆開 2 例, イレウス 1 例であり，再手術を 必要としたのは創哆開の 2 例であつた。照射および手 術後の合併症として, 心筋梗塞, 胃出血, 回腸導管出 血，尿管皮膚瘦術後狭窄，脳出血が各 1 例認められ， 狭容例は再手術を必要とした。脳出血の 1 例は手術後 1 力月以内発生例である。
(1) 術前照射の意義

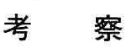
浸潤型膀胱癌に対する治療として, 膀胼全摘除術が

図 2（a）照射前

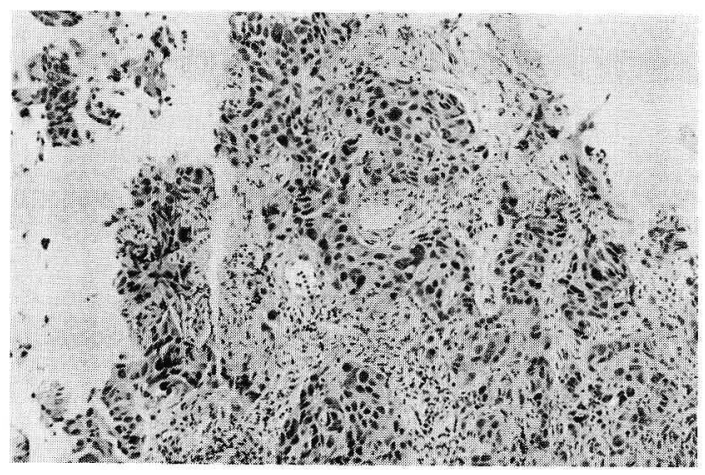

図 2 (b) 照射後

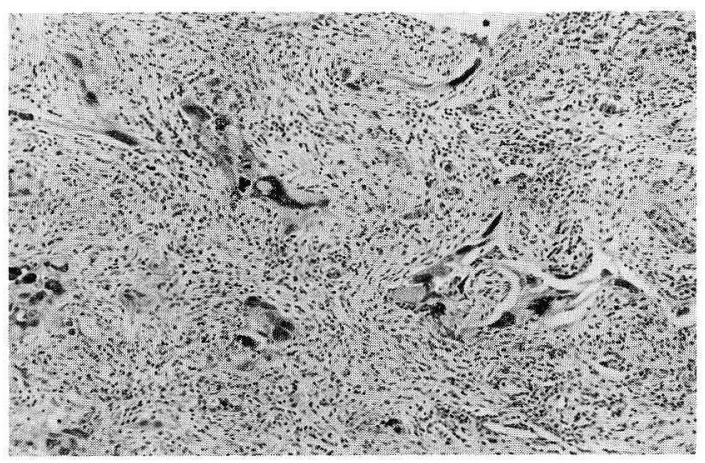

表 7 術後合併症( 7 例，32\%)

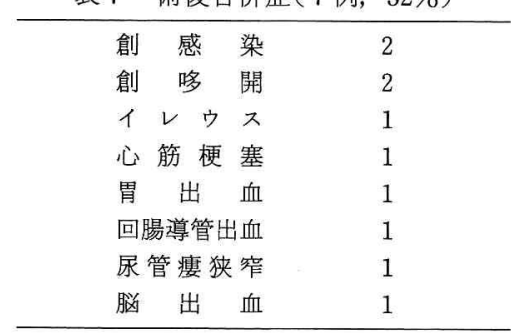

主流となりつつあるが，その予後はいまだ満足すべき ものとなつていない. 我々の集計でも 3 年生存率 $47 \%$ であり，死因の大部分は局所再発を伴つた癌死であ る ${ }^{3)}$. 高安ら ${ }^{4)}$ 報告でも, high stage 群の膀胱全摘症 例の 5 年生存率は $9 \%$ 之低く, 死亡例の大半が 2 年以内 の死亡である。

局所再発を抑光，生存率を改善するための試みとし て術前照射が主として欧米に执いて検討されてきた。 Whitmore ${ }^{5)} 1968$ 年最初に術前照射により生存率が 改善されることを報告し，以来 Bloom ${ }^{6)}, \mathrm{Miller}^{7)}$, $\mathrm{Edsmyr}^{8)}$ らは放射線単独治療と比較し, 術前照射と膀 
胱全摘がすぐれていることを報告し，また Salvage Cystectomy の有用性も報告している。 Barzell ら99 は 膀胼全摘単独と比較して術前照射群の予後が良好であ ると述べている，術前照射により局所再発が抑制され ることは, Skinner ${ }^{10)}$ の報告で局所再発が5\%であつた ことからもらかが党る. Shipley ${ }^{11)}$, Dewerd ${ }^{12)}$, Skinner ${ }^{10)} ら は$ 照射により down stage effect が得ら れ，手術の根治性が増す期待がもてるとしている。

(2) 線源，線量，照射野について

今回の報告はサイクロトロンを使用する機会に恵を れリニアックとの比較で術前照射を行つたが，報告

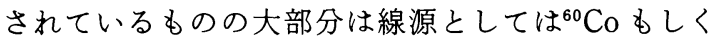
はリニアックを使用している。線量は1,600 rad $\left(\right.$ Skinner $\left.{ }^{10)}\right)$ から5,000rad (Miller $\left.{ }^{7)}\right)$ まで種々の方法 が試みられ，未だ結論が出ていない，我々の選んだ線 量は，比較的短期間に照射でき，抗腫瘍効果もはつき り期待でさるといら意味で TDF60とした。

照射野は，所属リンパ節を含めた小骨盤全体に照射 している施設が多いようであるが，本報告では消化管 への被曝を最少限に抑兄るため, 膀胱とその近傍のリ ンパ節を含む狭い範囲にとどめ, リンパ節転移に対し ては徹底した郭清で対処する方針とした，又，検索り ンパ節には転移は $5.9 \%$ に認められるのみであり,リン パ節までの払大照射の必要性は乏しいと思われる。

(3) 効果判定について

術前照射の有用性の判定には以下の 3 つの要件を満 たす必要があると考学る。i）照射により抗腫瘍効果を 認めること，ii）局所再発率を低下させらること，iii） 生命予後を改善させらること.今回の報告の主な目的 は，i）の抗腫瘍効果の判定であり，そのための方法と して膀胜造影による腫瘍の大きさの比較と, Clinical stage と Pathological stage の比較, 及び病理組織学 的効果の判定の 3 点を選んだ。その他の方法について も検討したが，膀胱鏡検查では，浸潤型腫黇が大部分 の為数量的表現が困難であること，麻酔下双手診では 余り差を認められなかつたこと，CT では照射に伴う 組織反応を腫瘍と同様の CT 值で表現してしまらため 判定が困難であつたこと，などの理由により判定方法 から除外した。

膀胱造影の陰影欠損面積で $50 \%$ 以上の腫瘍縮小を認 めたもの, stage down effect を認めたもの, 病理組織 学的効果で GIIb 以上であつたもののうち，いずれか 1 つでも満足させたものを照射有効例とみなすと，22 例中14例 $(63.6 \%)$ が有効例であつた。 病理組織学的効果を異型度別に比較した場合，high

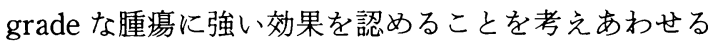
と, high grade な浸潤型膀胱癌は放射線照射に対しか なり良好な感受性を有しているものと考えられる，放 射線照射単独治療の検討で, low grade 群に比し high grade 群の治療成績が悪いとの報告があるが $\left(\right.$ 東 ${ }^{13)}$, 町 田 $\left.{ }^{14)}\right)$ ，このことは決して high grade 群の放射線感受 性が劣るといら意味ではないと思われる。すなわち， 放射線照射単独治療では high grade な膀胱癌の根治 は困難であると理解すべさであろう，放射線感受性を 照射前に判定する方法の開発が必要と思われる.

判定の要件として前述した ii）, iii）すなわち局所再 発率と生命予後に関しては，検討に足るだけの期間を 経過していないが，平均 10 力月の観察期間で，治癒切 除症例中には局所再発は認めておらず，当教室の過去 の集計と比較しても良好な結果が期待できる状況であ る.

(4) 速中性子線の臨床効果について

日本に抢ける速中性子線による臨床トライアルは, 1975年11月放射線医学総合研究所において開始され， 子宮頝癌, 肺癌, 頭䅡部癌, 泌尿器癌15), 骨肉腫, 悪性 黒色腫, 脳腫瘍, 消化器癌, 軟部組織肉腫などにおい て成果をおさめつつある16) 19). 従来の X 線照射との治 療成績の比較検討については，久津谷ら ${ }^{201}$ の報告にあ るように, 生物学的等価線量を計算し, TDF を算出す ることで，単独照射， Mixed beam, boost 治療などの 相互比較が可能である.今回のトライアルにおいても, リニアックとサイクロトロンそれぞれの使用群の照射 量を $\mathrm{TDF}=60$ と同値にそろ光，その照射効果を比較し た。結果は腫湯縮小効果, Stage down effect で若干サ イクロトロンが優れ，病理組織学的効果ではほぼ同程 度であつた。ただし，速中性子線照射による抗腫瘍効 果が最も大きくなるのは照射終了後 2 週間を経過した 頃であると思われるので，今後は照射終了後手術まで の期間を 2 週間に延ばして検討していく予定である.

(5) 副作用と術後合併症

照射による重篤な副作用や手術死亡，術後合併症の 有意な増加は報告されていないようであり，術前照射 は安全にできると考光られる。今回の報告に拈いても， 照射計画を变更する必要のあつた副作用は 1 例もな く, 手術死亡は 1 例 (4.5\%), 術後合併症も 7 例 (32\%) と照射を併用しなかつた時期と比較して特に上昇して はいない。 


\section{結語}

(1) 原発性膀胱腫瘍患者22例に対し,サイクロトロン 速中性子線910 rad もしくはリニアック X 線 $3,000 \mathrm{rad}$ を術前照射し，膀脱全摘除術を施行した。

(2) 近接効果として，5例に $50 \%$ 以上の腫瘍縮小を認 め, 8 例 $(38 \%)$ に Stage down effectを認めた。病 理組織学的には GII 以上の効果を15例（79\%）に認め た。速中性子線照射例に有効例が多かつた。

(3) 予後は治癒切除を行えた19例中, 局所再発はな く，1例が肺転移により死亡した。

(4) 軽度の副作用を $50 \%$ に認めた. 術後合併症は 7 例 (32\%) に認めた。

（な体本論文の要旨は第20回癌治療学会総会に拈いて発 表した.)

\section{文献}

1) 日本泌尿器科学会, 日本病理学会編：泌尿器科・病 理・膀脱癌取扱、規約. 第 1 版, 金原出版株式会社, 東京, 1980.

2) 大星章一, 下里幸雄, 板倉克明, 梅垣洋一郎: 癌放 射線療法の病理. 医学のあゆみ, 第61巻, p. $618-730,1967$.

3）五十嵐辰男, 井坂茂夫, 秋元 晋, 村上光石, 島崎 淳, 松崔 理, 村上信乃：浸潤性膀胼癌に対する膀 胼全摘術の検討. 投稿中.

4) 高安久雄, 小川秋実, 北川龍一, 柿沢至恕, 岸 洋 一, 赤座英之, 石田仁男 : 膀胱腫崵の治療成績. 日 泌尿会誌, 69，669-678，1978.

5) Whitmore, W.F. Jr., Grabstald, H., Mackenzie, A.R., Iswariah, J. and Phillips, R.: Preoperative irradiation with cystectomy in the management of bladder cancer. Amer. J. Roentgen, 102, 570, 1968.

6) Bloom, H.J.G., Hendry, W.F., Wallace, D.M. and Skeet, R.G.: Treatment of T3 bladder cancer. Controlled trial of pre-operative radiotherapy and radical cystectomy versus radical radiotherapy. Brit. J. Urol., 54, 136-151, 1982.

7) Lowell S. Miller, M.D.: Bladder cancer superiority of preoperative irradiation and cystectomy in clinical stage B2 and C. Cancer, 39, 973-980, 1977.

8) Edsmyr, F. and Johansson, B.: Bladder carcinoma treated by preoperative radiotherapy followed by cystectomy. Urological Research, 6, 253-254, 1978.
9) Winston Barzell and Willet F. Whitmore, Jr. : Radiocal cystectomy with or without planned preoperative irradiation in the treatment of bladder cancer. Urological Research, 6, 249-251, 1978.

10) Donald G. Skinner, Jerome P. Tift and Joseph J. Kaufman: High dose, short course peroperative radiationtherapy and immediate single stage radical cystectomy with pelvic node dissection in the management of bladder cancer. J. Urol., 127, 671-674, 1982.

11) Shipley, W.U., Cummings, K.B., Coombs, L.J., Hawkins, I.R., Einstein, A.B. and Penick, G. : 4000 rad preoperative irradiation followed by prompt radical cystectomy for invasive bladder cancer: A prospective study of patient tolerance and pathologic down staging. J. Urol., 127, 48-51, 1982.

12) James H. Deweerd, Malcolm Y. Colby Jr., Robert P. Myers and Roger E. Cupps: Cystectomy after radiotherapeutic ablation of invasive transitional cell cancer. J. Urol., 118, 260-261, 1977.

13）東嚴：膀胱癌の放射線治療. 日本臨床, 35 , 1774-1776, 1977.

14）町田修三, 吉田 修, 阿部光幸 : 膀胱癌の放射と治 療一特に 5 -FU との併用療法について。, 日本臨床, 35, 1780-1783, 1977.

15）伊藤晴夫：粒子線と手術とによる泌尿器癌の治療 効果改善に関寸る研究. 厚生省がん研究助成金に よる研究報告集, 94, 1981.

16）恒元 博, 梅垣洋一郎, 森田新六, 荒居竜雄, 浦野 宗保, 栗柄 明, 川崎勝弘, 平岡 武, 星野一雄, 稲田哲雄, 久津谷譲, 岡崎 実, 熊谷和正 : 放医研 サイクロトロンによる速中性子線治療トライア ル。癌の臨床, 23, 319-326, 1977.

17）森田新六, 恒元 博, 梅垣洋一郎, 浦野宗保, 荒居 竜雄, 栗柄 明：放医研サイクロトロンによる速 中性子線治療の臨床経験。癌の臨朱, 23, 1136-1141, 1977.

18）恒元 博, 荒居竜雄, 森田新六, 石川達雄, 中野政 雄：放医研における速中性子線治療とその評価. 癌の臨床, 24, 1001-1008, 1978.

19）恒元 博：癌 - 放射線療法. 癌の臨床別冊新編, 137-147, 篠原出版, 東京, 1978.

20）久津谷譲, 古川重夫, 梅垣洋一郎, 恒元 博, 飯沼 武：速中性子線治療に打ける病巣線量括よび線量 分布の計算. 癌の臨床, 23, 284-295, 1977. （1982年 2 月 25 日受付） 